\title{
Advances in Technology and Cultural Heritage
}

\begin{abstract}
By Rozmeri Basic ${ }^{*}$
Professor Colin Renfrew, Senior Fellow of the McDonald Institute for Archaeological Research, University of Cambridge, delivered the first Marija Gimbutas Memorial Lecture at the Oriental Institute, University of Chicago, on November 8, 2017. In this lecture, Renfrew discussed the Indo-European populations based on recent DNA analysis of human remains found in ancient burial sites. In addition, Renfrew backed up the established theory of Minoan and Mycenaean origins, relevant to Kurgan invasion and Anatolian migration. However, he failed to point out the possibility of the use of technological advances in science to further explore theories of origin of cultures with no written language records including, for example, the Cycladic culture. The goal of this paper is to discuss some of latest discoveries relevant to the Aegean Neolithic and Bronze Age periods and the infinite or/and limited possibilities of reshaping our understanding of the past.
\end{abstract}

\section{Introduction}

In recent years, there has been increasing use of technology in every area of human activity, including disciplines that may be considered traditional for their use of conventional research methodology. Personally, I was never thrilled to see the destroyed Temple of Bel in Syria on display in the middle of London's Trafalgar Square and on the streets of New York using 3D printer technology, or to listen to the "reconstructed" voice of Leonardo's Mona Lisa created by Japanese tech wizards (Figure 1). ${ }^{1}$

However, recent articles published since 2013 by a group of scientists using the latest genome analysis of ancient DNA have resulted in my appreciation of technological advances used as tools in the humanities. ${ }^{2}$ These studies represent scientific contributions to various hypotheses formulated over the years, with two being dominant. ${ }^{3}$ The first, defined by Renfrew, included the analysis of languages used in Europe during 8,000-3,000 BCE, spread by migration from Anatolian geographic proper. ${ }^{4}$ The second, defined by Gimbutas, preferred the idea of "Kurgan" invaders from the Russian steppes who arrived in several phases during the period 4400-2500 BCE. ${ }^{5}$

*Professor of Art History, University of Oklahoma, USA.

1. For both events, see articles by Cat diStasio, World's largest $3 D$ printer will recreate ISIL-destroyed Syrian ruins in London and New York https://bit.ly/2SJGxrw and by Associated Press, Mona Lisa speaks...virtually, https://nbcnews.to/2SJGwUu.

2. See the sources in footnote 5 on the next page.

3. For a summary of all the hypotheses, see Marija Gimbutas, The Indo Europeans: Archaeological Problems. In American Anthropologist, 65, no.4 (August 1963), 815-816.

4. Colin Renfrew, The Origin of Indo-European Languages. In Scientific American, 261 no. 4 (October 1989), 108.

5. Renfrew (1989) 111. Kurgans are earthen mounds (in Russian, a type of tomb).

https://doi.org/10.30958/ajhis.5-2-4

doi=10.30958/ajhis.5-2-4 


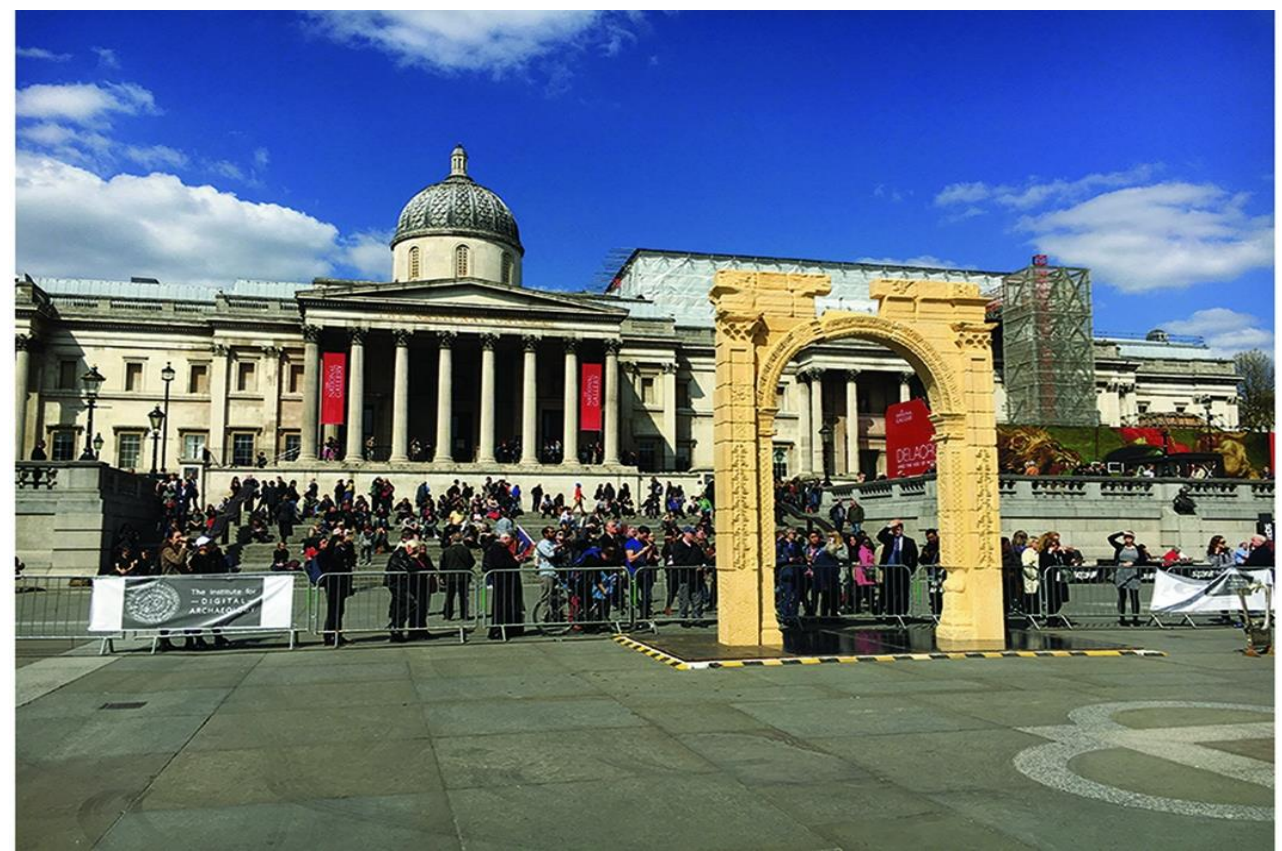

Figure 1. The replica arch from the Temple of Bel at Palmyra, standing in Trafalgar Square, London (image courtesy of the Institute of Digital Archaeology)

Source: https://bit.ly/2EfGZox.

To support their theories, these scholars based their research on different methodologies: Renfrew on archeological empirical research and Gimbutas on an interdisciplinary approach combining fields of archeology, art history, linguistics, anthropology, and archaeomythology (archaeology and mythology). Before recent studies on ancient DNA, a major research focus was on the first preserved written records. ${ }^{6}$ Therefore, the origin of European civilizations and cultures with no preserved written records lacked crucial components to support or deny existing theories of their origins. For example, despite the fact that Aegean civilization had left great riches of artifacts and monumental architecture in the case of the Minoans and Mycenaeans, the preserved record of their literate societies (hieroglyphs, Linear A, and Linear B scripts), the oldest Cycladic culture with no written records, remained in limbo regarding any focused study on genetics and/or linguistics. However, with technological advances, it is now possible to shed some light on these important issues.

The goal of this paper is to emphasize the constructive recent results of genetics and DNA analysis of ancient human remains to establish the common source of European populations, with a special focus on the Aegean late Neolithic and early Bronze Age cultures. However, it is beyond the scope of the paper to list all available material on the topic. Instead, I have included the most

6. Accrediting Sumerians for writing around 3,500 BCE. 
relevant sources on the origin of the European populations and linguistics mentioned in the text. These are listed in chronological order of publication. ${ }^{7}$

\section{Hypotheses of Renfrew and Gimbutas}

Renfrew's approach to the origin of European populations is to connect it with the Indo-European languages. His opinion is that "the spread of agriculture from its origins in Anatolia and the Near-East," ${ }^{8}$ resulted in the peaceful expansion of languages in prehistoric Europe. Furthermore, in his study Renfrew compares words from several European languages with the Sanskrit to demonstrate similarity in vocabulary. ${ }^{9}$ He also acknowledged the fact that the Greek language belonged to the Indo-European family of languages, and without too much evidence, believed that a migration of Greek (or IndoEuropean) speakers into mainland Greece occurred during the Bronze Age. ${ }^{10}$ It is also generally known fact that during the Neolithic period the Greek

7. Selected publications on the topic consulted for this paper: Iosif Lazaridis, Swapan Mallick, Alissa Mittnik, et al., "Genetic origins of the Minoans and Mycenaeans," in Nature 548 (August 2017), 1-17; Wolfgang Haak, Iosif Lazardis, Nick Patterson, et al., "Massive migration from the steppe was a source for Indo-European languages in Europe," in Nature 522 (June 2015), 207-211; Soren Wichmann, Neolithic Linguistics, Max Planck Institute for Evolutionary Anthropology \& University of Copenhagen (2004), 1-26, https://bit.ly/2TS45qU; Mara Lynn Keller, "Theory of Early European Origins and the Contemporary Transformation of Western Civilization," in Journal of Feminist Studies in Religion, 12, no. 2 (Fall, 1996), 73-90; Andrew Fleming, "The Myth of the Mother Goddess," in World Archaeology, 1, no. 2 (October 1996), 247-261; Cyprian Broodbank, "Ulysses without Sails: Trade, Distance, Knowledge and Power in Early Cyclades," in World Archaeology, 23, no 3 (February 1993), 315-331; Robert Sokal, Neal Oden, and Barbara Thomson, "Origins of the Indo-Europeans: Genetic Evidence," In Proceedings of the National Academy of Sciences of the United States of America, 89, no. 16 (August 15, 1992), 7669-7673; Colin Renfrew, "The Origins of Indo-European Languages," in Scientific American , 261, no. 4 (October 1989), 106-115; Cyprian Broodbank, "The Longboat and Society in the Cyclades in the Keros-Syros Culture," in American Journal of Archaeology, 93, no. 3 (1989), 319-337; J.P. Barber Mallory, In Search of Indo-Europeans (London: Thames and Hudson, Ltd., 1989); David W. Anthony, et al., "The 'Kurgan Culture,' Indo-European Origins, and the Domestication of the Horse: A Reconsideration," in Current Anthropology, 27, no. 4 (August-October 1986), 291-313; R.L.N. Barber, and J.A. MacGillivray, "The Early Cycladic Period: Matters of Definition and Terminology," in American Journal of Archaeology, 84, no. 2 (April 1980), 141-157; Tamara Stech Wheeler, "Early Bronze Age Burial Customs in Western Anatolia," in American Journal of Archaeology, 78, no. 4 (October 1974), 415-425; John E. Coleman, "The Chronology and Interconnections of the Cycladic Islands in the Neolithic Period and the Early Bronze Age," in American Journal of Archaeology, 78, no. 4 (August 1974), 333-344; Colin Renfrew, The Emergence of Civilization: The Cyclades and the Aegean in the Third Millennium BC (Oxford, UK: Oxford and Oakville, 1972/2011); Lawrence J. Angel, "Early Neolithic Skeletons from Catal Huyuk: Demography and Pathology," in Anatolian Studies, 21 (1971), 77-98; Marija Gimbutas, "The Indo-Europeans: Archaeological Problems," in American Anthropologist, 65, no. 4 (August, 1963), 815-836; James Mellaart, "The End of the Early Bronze Age in Anatolia and the Aegean," in American Journal of Archaeology, 62, no. 1 (January 1958), 9-33; Marija Gimbutas, "An Ancient Art of Hunters and Fishers," in Archaeology, 8, no. 4 (December 1955), 268-277.

8. Renfrew, 1989, 106.

9. Idem.

10. Renfrew, 1972, XLVIII. 
language was conveniently labeled as "pre-Greek." With regard to the Aegean island populations, including the Cyclades, earlier scholarship refers to it being formed by "a group of people with a culture distinct from but having its closest ties with the mainland of Greece. ${ }^{11}$ Additionally, it is acknowledged that at the end of either the fourth or early third millennium, the island of Kea was occupied by another group of people, who were closed to the population of Attica. $^{12}$

As an archeologist, Renfrew continued to address his frustration with the lack of sufficient material evidence to support his complex linguistic theory (Figure 2). Especially interested in Cycladic culture, he often emphasized the negative consequences of the looting of burial sites and the vague provenance of preserved artifacts on display in numerous European and US museums. Inevitably, he acknowledged that burial customs were not a proper model to establish chronology in this case. However, chronology was needed to classify the existing properly documented material. ${ }^{13}$

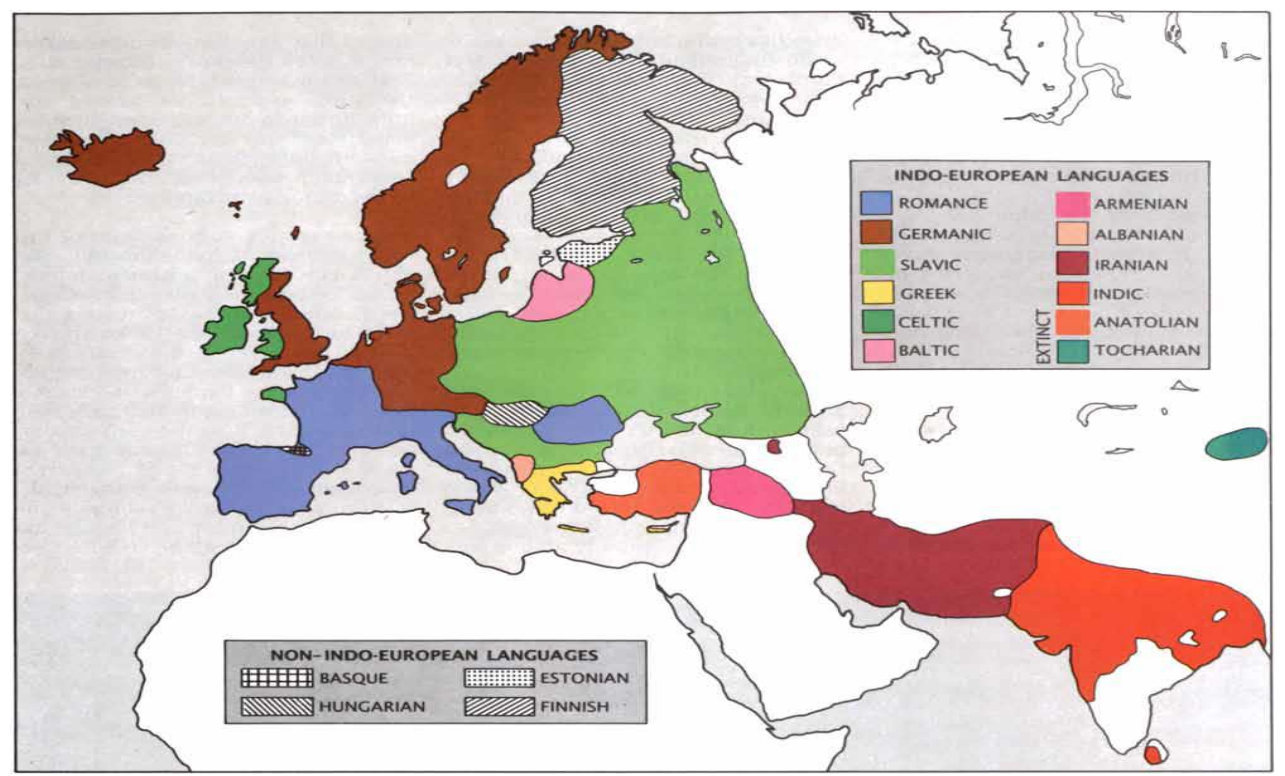

Figure 2. Indo-European languages are distributed from Ireland to India, and almost all the languages of Europe fall into this family (except Finnish and Hungarian, in the Finno-Ugric group, and Basque)

Source: Renfrew, 1989, 108.

11. Coleman, 1974, 343. The most famous artifacts originating on the Cycladic islands, marble figurines, were created during 3000-2200 BCE, therefore belonging to the Bronze Age period, although the islands were inhabited from the fifth millennium. For details, see Pat GetzPreziosi, Early Cycladic Sculpture, an Introduction (Malibu, Ca: The J. Paul Getty Museum, 1994).

12. Idem.

13.The following is present-day chronology for Cycladic culture: Early Cycladic I-

Grotta-Pelos Culture (ca. 3100/3000-2650 BCE)

Early Cycladic IIA-Keros-Syros Culture (ca. 2650-2450/2000 BCE)

Early Cycladic IIB/IIIA-Kastri Group or Lefkandi I Culture

(ca. 2450/2000 BCE-2200/2150 BCE)

Early Cycladic IIIB/Middle Cycladic IA-Phylakopi I Culture (ca. 2050/2000-1900/1850 BCE). 
Due to the geography of the Cycladic islands, it was logical to expect the existence of developed trade and therefore communication along the Mediterranean coast of the Levant and Anatolia through established maritime routes. ${ }^{14}$ As the settlements and cemeteries were typically modest, artifacts were limited to small-sized objects in single burials. In addition, there was diversity in grave types, which suggested a great cultural diversity. ${ }^{15}$ The already mentioned trade with the Levant and the use of specific so-called longboats (especially during the Keros-Syros phase) gave partial support to Renfrew's hypothesis based on Anatolian connections (Figure 3). ${ }^{16}$

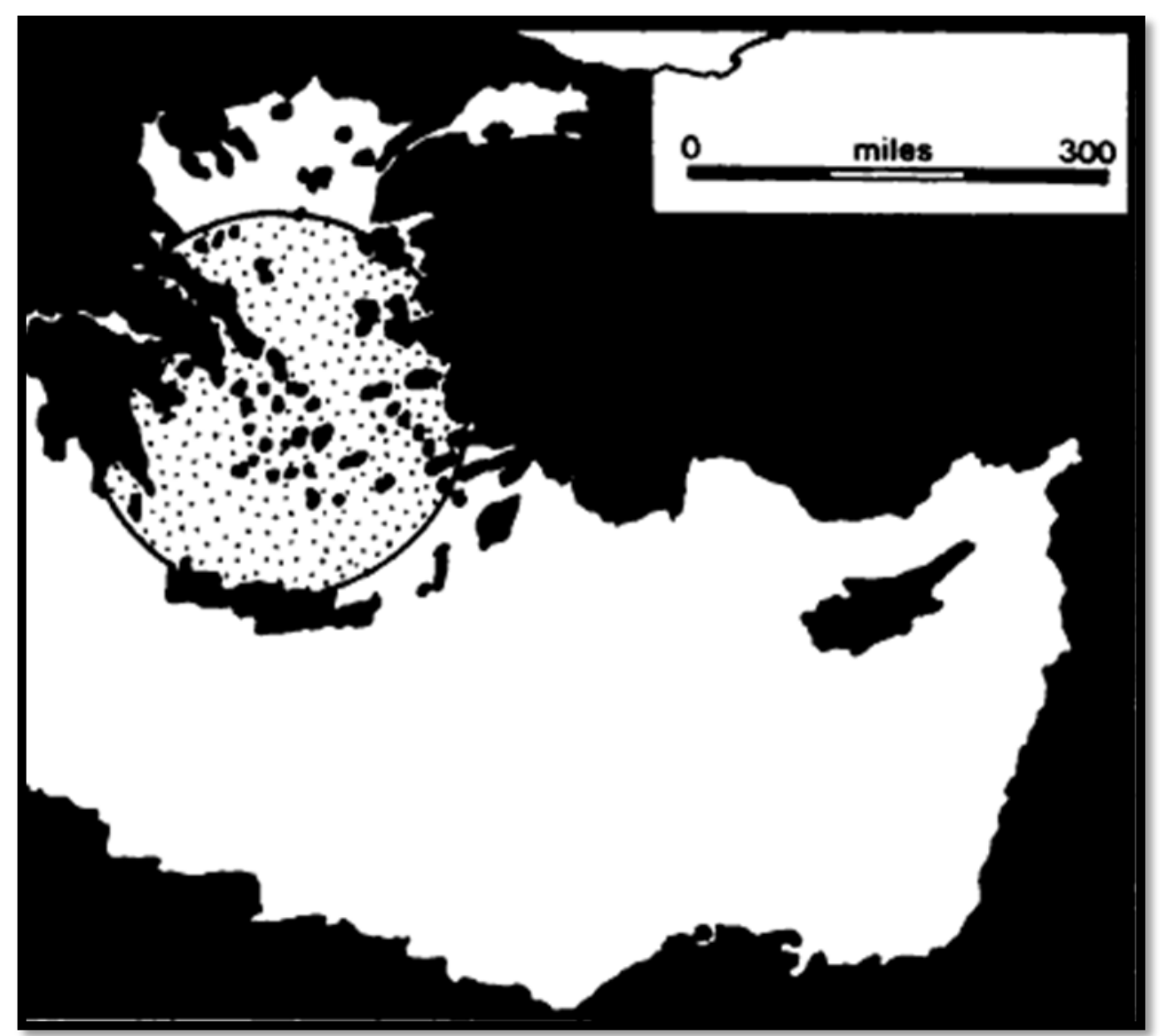

Figure 3. The Aegean and Eastern Mediterranean, depicting the estimate of the notional range of a longboat voyage of two weeks Source: Broodbank, 1989, 334.

With limited number of publications on Anatolia linguistics, it has been established that all known languages of Bronze Age western and central Anatolia belong to the Indo-European family (with the inclusion of the Hittite and Luwian languages). ${ }^{17}$ Therefore, in 2011, Renfrew was contemplating the

14. For detailed study see Broodbank, 1993.

15. Coleman, 1974, 336.

16. Broodbank, 1989, 326.

17. Renfrew, 2011, XLIX. Only the so-called Hattic language is related exclusively to Bogazkoy capital. 
idea of Minoan language derived from early proto-Indo-European ancestors in Anatolia. ${ }^{18} \mathrm{He}$ also reexamined the possibility that the "Coming of the Greeks," to this part of the land never happened due to the fact that the Greeks were autochthonous. ${ }^{19}$ Their origin goes back to the Neolithic period with the arrival of the first farmers to the Aegean land from Anatolia and the Greek language took shape during the same time. Renfrew also emphasizes a notion of socalled "linguistic replacement." ${ }^{20}$ In many cases, the languages of indigenous populations have come to be replaced by the outsiders: migrants or invaders. According to Renfrew, this is a key to discovering the origin of the European populations.

In the case of migrants, language replacements occurred peacefully due to perhaps technological implementation in the already existing and sophisticated economic and social system, such that the expansion and increasing quality of lifestyle made the new language gradually dominant. In the case of superior military technology, the likelihood of invaders forcefully imposing their language over local populations was the expected outcome. Renfrew encountered some resistance with his Anatolian hypothesis and Gimbutas was one of his main challengers. Her hypothesis of Kurgan invasion was not totally discarded by him, but he considered that the invasion took place instead after the Anatolian migration (Figure 4). ${ }^{21}$

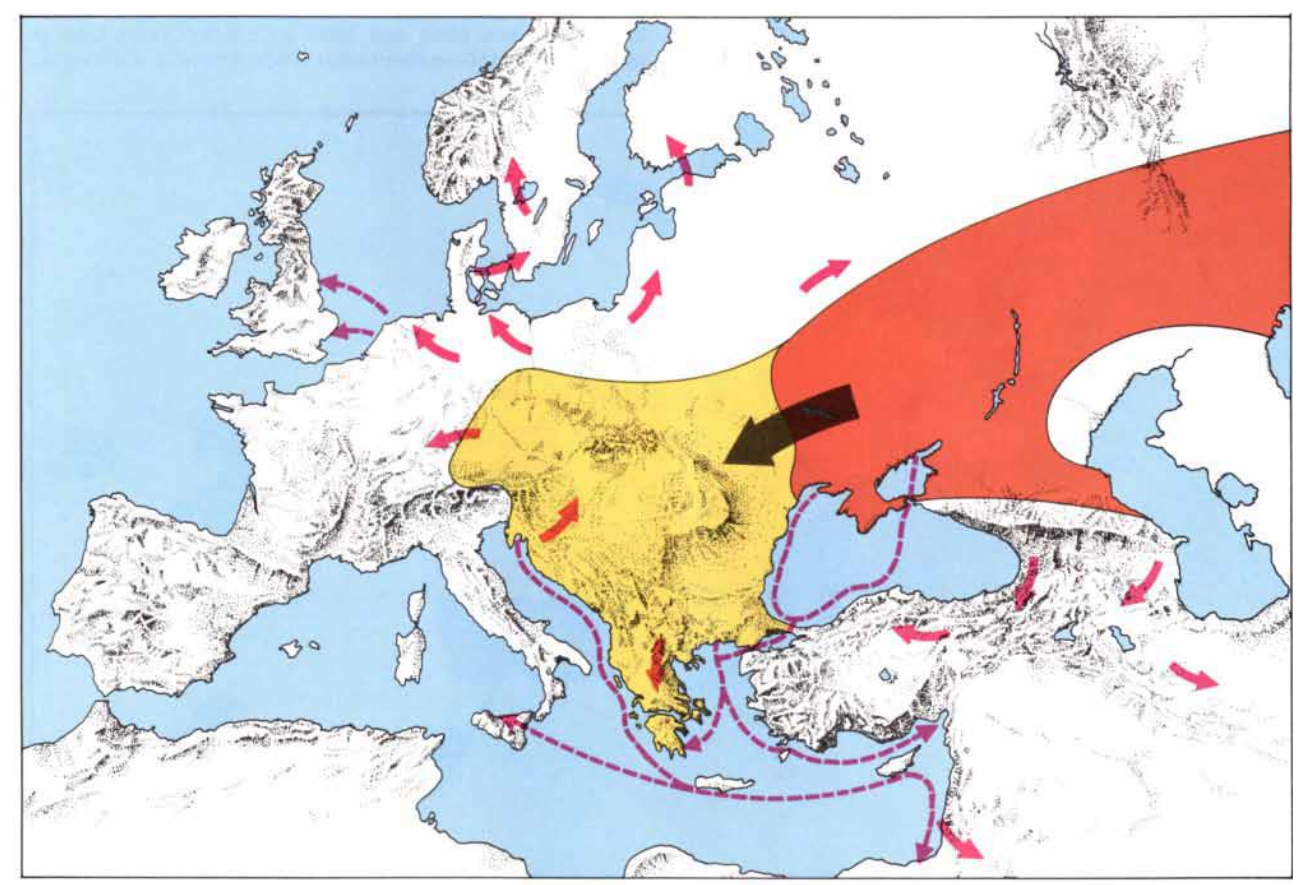

Figure 4. The "Kurgan Invasion" hypothesis pictured the original IndoEuropeans as mounted warriors ranging out from a homeland north of the Black Sea beginning in about 4400 B.C. This map is based on one drawn by Marija Gimbutas of the University of California at Los Angeles. The first wave

18. Idem.

19. Renfrew, 2011, L.

20. Renfrew, 1989, 109.

21. Ibid. 111. 
of invasions (orange), according to the model, brought the warriors to Greece by about 3500 B.C. Thereafter, they spread north and south; the colored arrows show their movements after about 2500 B.C.

Source: Renfrew, 1989, 111.

According to Gimbutas, Neolithic Europe was a matristic and peaceful goddess-worshiping civilization. It was overrun by patriarchal, horse-riding and sky-worshiping Kurgan invaders who came from the Russian steppes in several phases during 4400-2500 BCE. ${ }^{22}$ These invaders brought with them different burial customs, especially for privileged male members of the communities, known as "chieftain graves." These were monumental entombments, which in addition to the deceased, included weapons, gold artifacts, sacrificed animals, members of the family (women and children), and servants. ${ }^{23}$ According to the author, these invaders did not exterminate the indigenous population immediately, but over time through the coexistence of different cultural elements and a process of hybridization led to eventual assimilation. ${ }^{24}$

This is a rather different view from Renfrew's depiction of the invaders, who due to technological superiority replaced the local language with their own almost at once. However, the possibility of gradual dominance is also acceptable as part of Gimbutas's invasion hypothesis and is based on geography. For instance, she mentioned several different routes that the Kurgans selected on their way to Europe (Figure 5). In the case of the Balkans, and most specifically the Aegean proper, in addition to the land roads, they used the sea route via the lower Dnieper area and after the conquest on the North Pontic culture.

It has been further suggested that most of the island populations may have joined the seaborne invaders and led them through the Northern Cyclades, where they picked up elements of the Syros group, to the East coast of Greece, where they settled around 2500 B.C. ${ }^{25}$ In this case, Renfrew's two additional theories on language replacement become possible. In the case of the total collapse of existing central control, the language of the invading "barbarians" may become dominant. ${ }^{26}$ The second, existence of the long-distance trade, may build up a so-called trading language amongst powerful community individuals. This is known as a pidgin language, commonly spoken by those who benefited directly from the trade. ${ }^{27}$

22. Gimbutas, 1963, 823.

23. Keller 83.

24. Gimbutas, 1963, 827. Her exact comment is "a gradual disappearance of local elements."

25. Mellaart, 1958.

26. Renfrew, 1989, 110. A good example is following the fall of the Roman Empire in 476 $\mathrm{CE}$ and the barbarian invasion.

27. Idem. This is a less acceptable theory simply because the island population of the time was quite small and without any sufficiently known class system (more studeis are needed on this topic). 


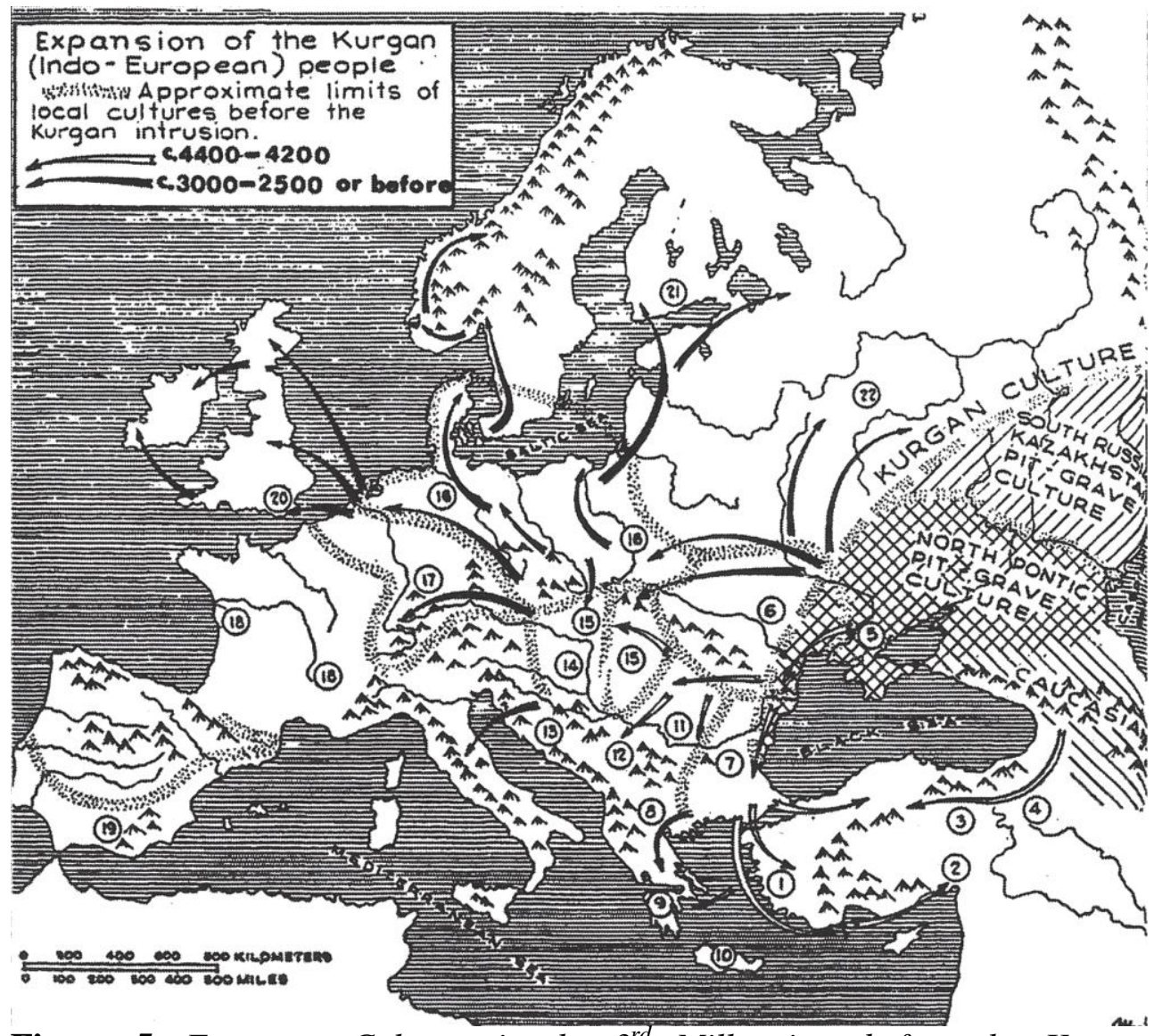

Figure 5. European Cultures in the $3^{\text {rd }}$ Millennium before the Kurgan Expansions

Source: Gimbutas, 1963, 826-827.

There is no doubt that Kurgans created a cultural shift, not only in burial practices, but in the social organization of communities in which the elderly and influential members of both sexes were honored, and replaced it with the sole supremacy of powerful and domineering males. Gimbutas's hypothesis and her nontraditional use of interdisciplinary methodology, including the fusion of anthropology with folklore and mythology, had provoked some doubts among empirical scholars, including Renfrew. However, technology became helpful to support many of her theoretical finds that she came upon using her unique research methods. The so-called Steppe hypothesis was based on her opinion that invaders from the Black and Caspian shores migrated to Europe around 4400 BCE causing the spread of Indo-European languages in Europe. ${ }^{28}$ One of the reasons for being so triumphant was the invention of the wheeled vehicles that gave them technological advantages over the existing population (Figure 6) ${ }^{29}$ In addition to mobility, chariots improved trade as well

28. Idem.

29. For a detailed description of wheeled wagons, see Natalia Shishlina, D.S. Kovalev, and Elmira Ibragimova, "Catacomb culture wagons of the Eurasian steppes," in Antiquity, 88 (June 2014), 378-394. 
as other aspects of communication with surrounding areas, enabling longer and safer travels.

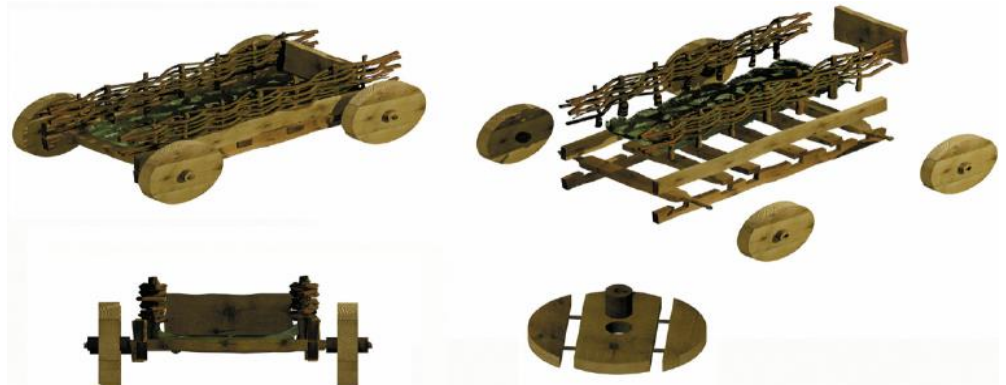

Figure 6. Reconstruction of the Typical Kurgan Wagon, made around 2300 $2200 \mathrm{BCE}$

Source: Shishlina, Kovalev, and Ibragimova, 2014, 387.

This technological advancement definitely favors Renfrew's already mentioned opinion of language replacement by the force of invaders who were superior over the indigenous population. In addition to language replacement, religion and other cultural aspects of daily life became transformed resulting in so-called "Kurganized" culture. ${ }^{30}$ As a note, this expression was disputed by some scholars who proposed more focused references such as Yamnaya culture, Kurgan tradition, or the Yamnaya "aspect" of the Kurgan "tradition." ${ }^{31}$

\section{Technology in the Service of Rediscovering Our Cultural Heritage}

One of the earliest recent attempts to use technology to support either of the two hypotheses of the origin of European populations was in $1992 .{ }^{32}$ An article published by several scientists examined the genetic evidence available from modern Europeans by focusing on the correlations between the genetic and linguistic distances in Europe and came up with an interesting conclusion. ${ }^{33}$ In their research, various factors, such as geography and agriculture, as well as the possibility of migratory movements, were taken in consideration. In addition, they studied 25 genetic systems from 2,111 Indo-European speakers in Europe. ${ }^{34}$ In a rather complex diagram providing a summary of results, "neither of two theories appears to be able to explain the origin of the IndoEuropeans as gauged by the genetics-language correlation (Figure 7)." ${ }^{35}$

30. Anthony, Bogucki, Comşa et al., 1986291.

31. Ibid. 292.

32. Sokal, Oden, and Thomson, 1992, 7669.

33. Idem.

34. The explanation of the rather complex mathematical formulas used by the researchers is beyond my art history background.

35. Sokal, Oden, and Thomson, 1992, 7669. 


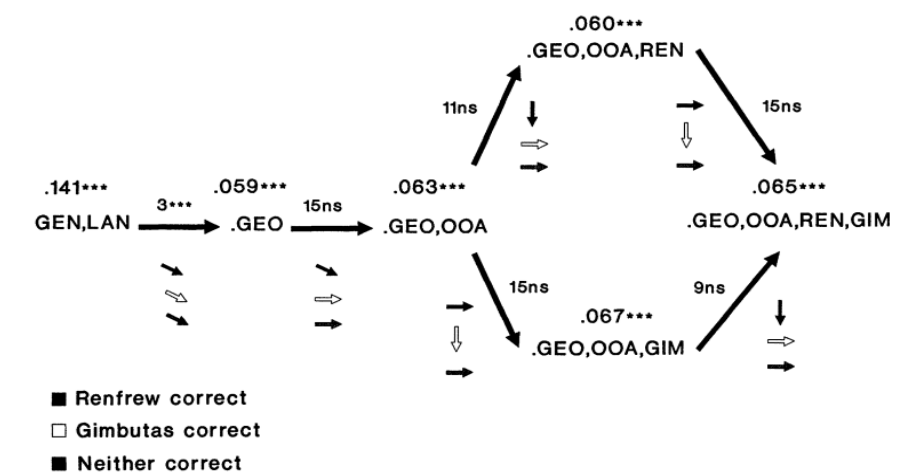

FIG. 3. Summary of results. The large arrows indicate successive steps in computing zero- to fourth-order partial correlations between genetic (GEN) and linguistic (LAN) distances. Other distances successively held constant are geography (GEO), origin of agriculture (OOA), Gimbutas (GIM), and Renfrew (REN). The numerical values at both ends of the large arrows are the average correlations from the bottom line of Table 1. They are all highly significant $(P<<0.001)$. The numbers above the large arrows are the numbers of genetic systems (out of 25$)$ that respond counter to expectations when an added distance matrix is held constant. The symbols following these numbers give the results of a one-tailed sign test (22) of the positive and negative changes to the correlations during the operation indicated by the arrow [ns (not significant), $P>0.05$ ***, $P<0.005$ ]. The three small arrows beneath each large arrow furnish predictions made by each theory concerning the behavior of the partial correlations. From the top down the arrows represent Renfrew's theory, Gimbutas' theory, and the assumption that neither theory is correct. A horizontal small arrow predicts no effect, a downward sloping small arrow predicts a reduction in the magnitude of the partial correlations, and a downward vertical small arrow predicts a reduction of the partial correlation to nonsignificance. The small arrows illustrate that the predictions of

Figure 7. Summary of Results

Source: Sokal, Oden, and Thomson, 1992, 7673.

The authors acknowledged the fact of "significant correlations between genetic and linguistic distances among Indo-European speakers in Europe." Nevertheless, they were unable to explain how the origin of agriculture influenced the genetic-language correlations in Europe as suggested by Renfrew. Therefore, his hypothesis of the first Indo-European speakers who were farmers who in the "course of an entire lifetime moved only a few kilometers," could not be confirmed. ${ }^{37}$ In the case of Gimbutas's Kurgan invasion, she overlooked the possibility of peaceful population movements, resulting in mixing genes as shown by sensitivity tests conducted by genetic scientists. ${ }^{38}$

Therefore, both hypotheses remained in theoretical state during the last century. Fortunately, in a recent study from 2015, a group of scientists across leading US, Australian, European, and Russian research institutions "generated genome-wide data from 69 Europeans (34 male) who lived between 8,000 3,000 BCE by enriching ancient DNA for a target set of 400,000 polymorphisms." ${ }^{39}$

The following was the distribution of the genetic material. ${ }^{40}$

- 25 ancient samples from the literature; 3 Upper Paleolithic samples from Russia, 7 people of European hunter-gatherer ancestry, 15 European farmers (from Germany, Spain, Russia, Sweden, Hungary, Italy, and Luxemburg):

36. Ibid. 7671.

37. Renfrew, 1989, 11.

38. Sokal, Odal, and Thomson, 1992, 7671.

39. Haak, Lazaridis, Patterson et al., 2015, 1.

40. Ibid. 2. 
- 19 hunter-gatherers (43000-2600 BCE);

- 28 Early Neolithic farmers (6000-4000 BCE);

- 11 Middle Neolithic farmers (4000-3000 BCE);

- the Iceman (3300 BCE);

- 9 late Copper/Early Bronze Age individuals (Yamnaya 3300-2700 $\mathrm{BCE}$ );

- 15 late Neolithic individuals (2500-2200 BCE);

- 9 Bronze Age individuals (2200-1500 BCE);

- 2 Bronze Age individuals (1200-1100 BCE);

- 1 Iron Age individual (900 BCE).

According to thirty-nine authors who conducted this study, genome-wide analysis of ancient DNA has developed as a transformative technological tool for revising prehistory, providing information to support disciplines such as archaeology, art history, history, and linguistics (Figure 8). ${ }^{41}$

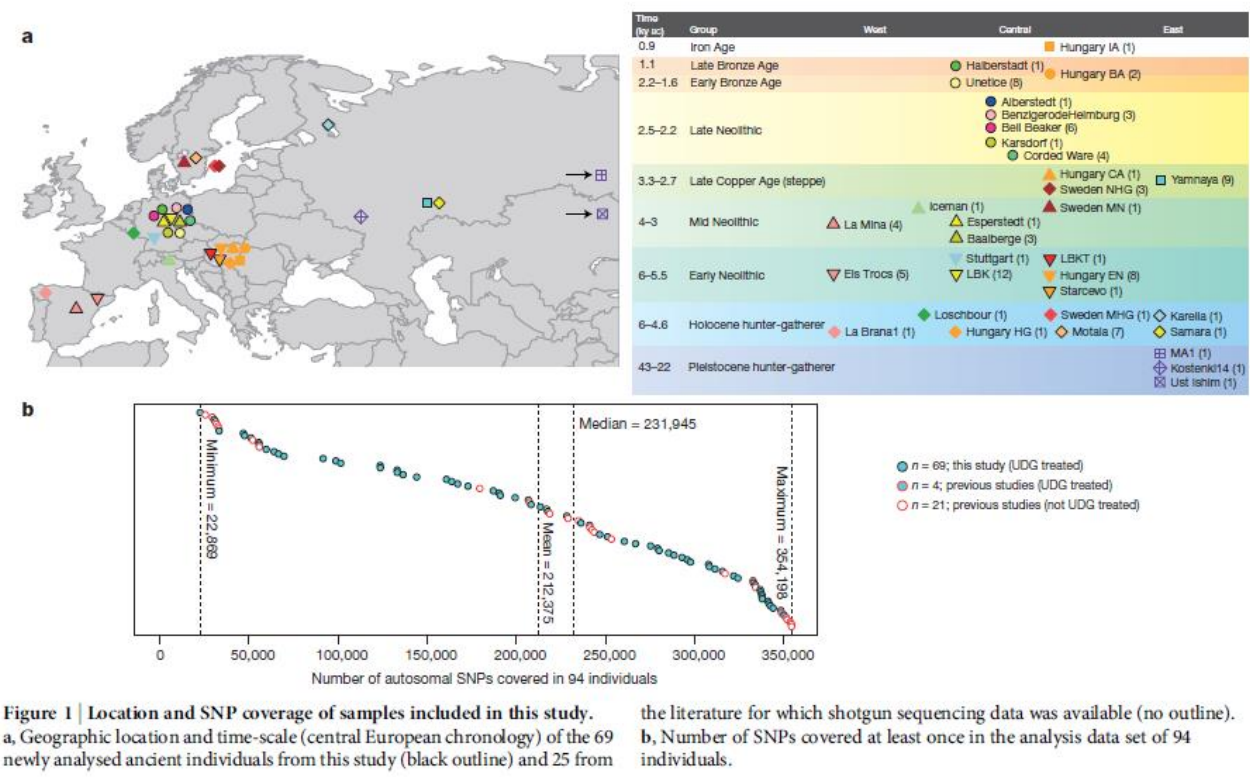

Figure 8. Geographic Location of the Included Genetic Samples

Source: Haak, Lazaridis, and Patterson et al., 2015, 2.

The authors published their analysis with several important conclusions; prehistoric Europe recorded two major migrations: first, the arrival of the first farmers from the Near East and second, the arrival of Yamnaya nomads during the late Neolithic period. ${ }^{42}$ Furthermore, both migrations were followed by a reappearance of the previous inhabitants during the middle-Neolithic and the late Neolithic and the present. In conclusion, all Europeans "can be modeled as a three-way mixture of western European hunter-gatherers, Early Neolithic, and Yamnaya." ${ }^{43}$

41. Ibid. 1.

42. Ibid. 4.

43. Idem. 
This study provided new data regarding the origin of Indo-European languages. The technology of ancient DNA made it possible to reject or confirmed the proposed migratory hypotheses and even to discover new events previously not known. ${ }^{44}$ The Anatolian hypothesis was challenged because "not all Indo-European languages in Europe can be plausibly derived from the farmer migrations thousands of years earlier." ${ }^{45}$ Additionally, the population of Europe at the time of the migration was so large that language replacement could not have happened. However, a later distressing event occurred when the steppe migrants replaced $75 \%$ of the ancestry of central Europeans. ${ }^{46}$ This means that Gimbutas's Kurgan invasion hypothesis was supported by the fact that invaders came to Europe around 4400 BCE. It is recorded as a massive migration movement (perhaps caused by technology-savvy invaders), that resulted in bringing the Corded Ware cultures and funeral tradition of monumental burial mounds ${ }^{47}$ (Figure 9).

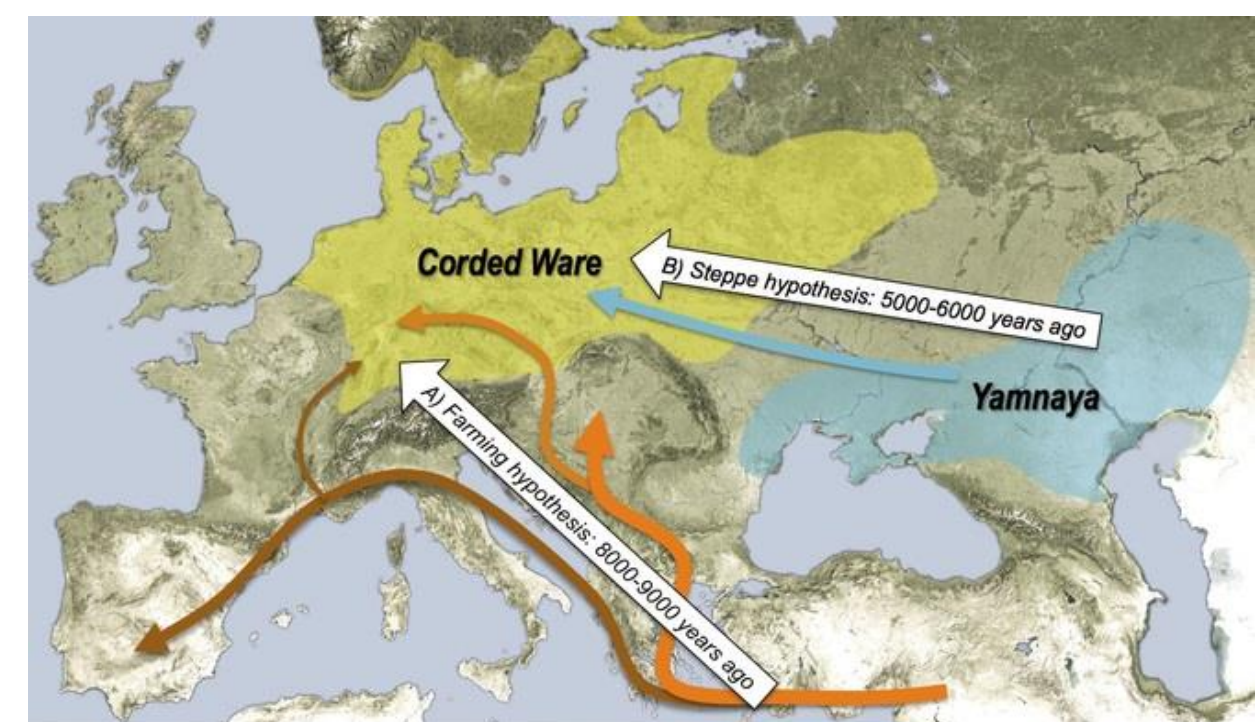

Figure 9. Map Depicting the Two Major Hypotheses of the Spread of IndoEuropean Languages (White Arrows) and Geographic Distribution of the Archaeological Cultures

Credit: Wolfgang Haak.

Source: https://bit.ly/2EhTy2O.

Many other issues need further research on the issues of the proto-IndoEuropean source of Indo-European languages in Asia and the other in Southeastern Europe. In addition, the Yamnaya culture needs more studies on ancient DNA and its present-day population.

44. Haak, Lazaridis, Patterson et al., 2015, 5.

45. Ibid. 5.

46. Idem.

47. Anthony, Bogucki, Comşa et al., 1986, 297. 


\section{The Aegean Case}

One of the reasons Renfrew formulated his Anatolian hypothesis was his scholarship of the Aegean civilization, with a special focus on the Cycladic culture. It is very well known that Anatolia and the Aegean islands have been communicating since prehistoric times and that their cultural connections were close. Unfortunately, as previously mentioned, many Cycladic sites were disturbed and the artifacts looted and scattered far from their original sites. However, with the research data from existing well-preserved sites, it is possible to determine with certainty that the Aegean coast and islands reveal a mixture of Anatolian and Aegean burial customs, with each site making an independent choice of procedures and types. ${ }^{48}$ One of the greatest problems in obtaining a comprehensive conclusion is that there are no detailed studies of the human skeletal remains found in western Anatolian cemeteries (only a few samples were included in the 2017 genetic study discussed later). The so-called Anatolian connection with the Cyclades is part of many studies and the comprehensive bibliography is included in Renfrew's book The Emergence of Civilization. ${ }^{49}$ In the updated edition from 2011, Renfrew slowly admitted that technological advances brought changes in understanding our past. ${ }^{50}$ Consequentially, many sites have been reassessed to obtain better and more precise data analysis. ${ }^{51}$

However, challenges remain. The very simple fact is that the social organization of the Early Bronze Age societies of the Aegean is not known. The use of seals and sealings in Minoan and Mycenaean cultures refers to a recording system, but not in present-day sense of what is known as "writing." 52 On the other hand, the Cycladic culture left no written records, but the wealth of artifacts suggests the existence of a highly organized belief system. In addition, based on archaeological evidence, trade and interaction with other cultures expanded. ${ }^{53}$ For example, in support of the economic connection, there is strong scientific evidence that the site of Kastri on Syros was an Anatolian fortified stronghold ${ }^{54}$ (Figure 10). Researchers have used new technological advances in chemical analysis to examine early bronze objects found in the site, with the date range of $2700-2300 \mathrm{BCE}^{55}$

48. Wheeler, 1974, 420.

49. Renfrew, 2011, XXXVII.

50. Idem.

51. According to Renfrew "it is a work in progresss."

52. Renfrew, 2011, XLIV.

53. Broodbank, 1989, 334.

54. Z.A. Stos-Gale, N. Gale, and G. Gilmore, "Early Bronze Age Trojan Metal Sources and Anatolians in the Cyclades," in Oxford Journal of Archaeology, 3, no 23 (May 2007), 23-24.

55. Idem. Kastri was a short-lived settlement of Anatolians who came most likely from Troy. 


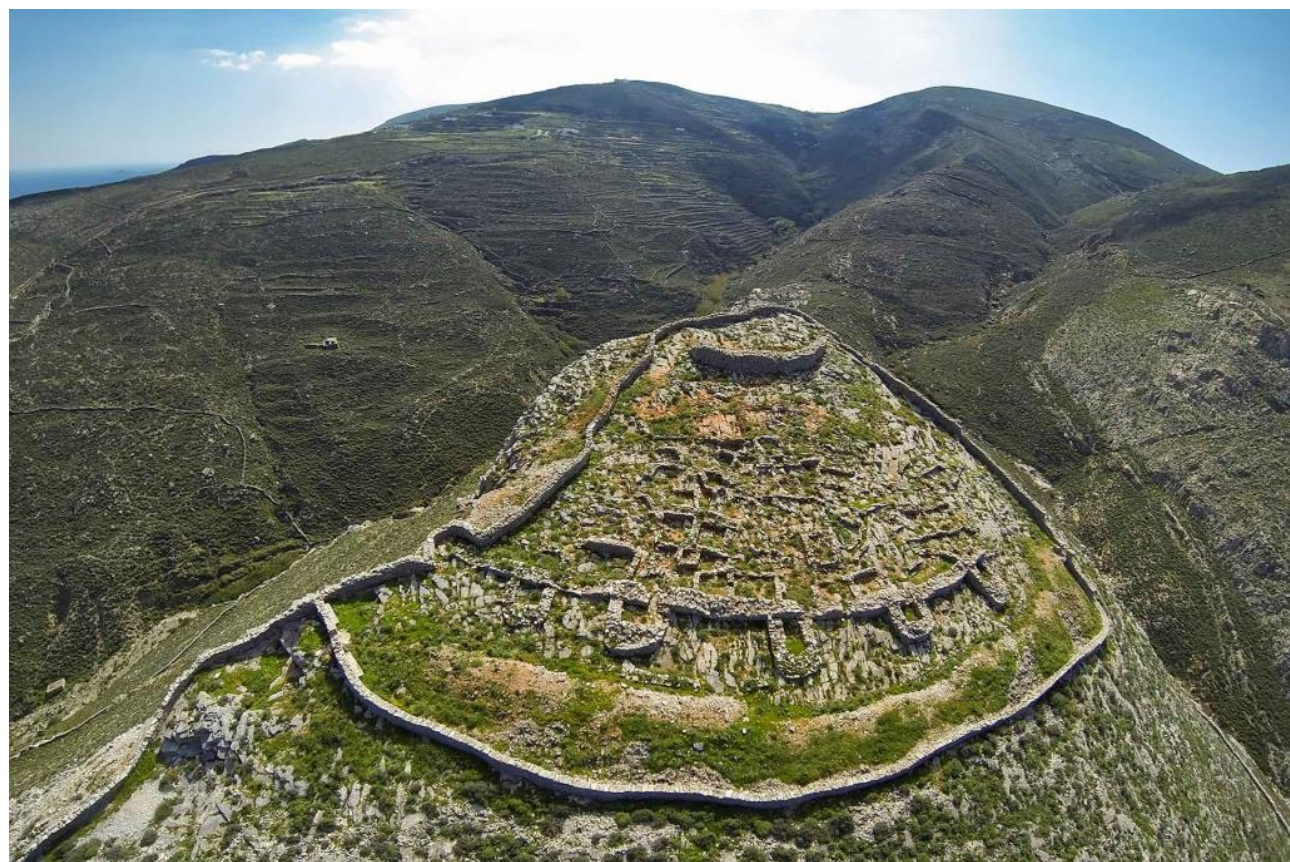

Figure 10. Kastri Fortifications on the Island of Syros

Source: https://bit.ly/2BFba72.

These metal objects included the following: crucibles, two molds for the casting of flat axes, spearheads and an arrowhead, a silver diadem, several objects of lead, and numerous other items. ${ }^{56}$ After careful analysis, it was concluded with certainty that these objects are Trojan, both in alloy type and in the provenance of the material. Moreover, a range of these objects are also of Trojan or Anatolian type. Perhaps they were brought from Troy where they were originally made in Kastri for Anatolian inhabitants. ${ }^{57}$ This provides evidence of close connections between the Cycladic and Anatolian populations and this definitely supported Renfrew's hypothesis of Anatolia as the "convenient" geographic, economic, and cultural center for transmitting diverse influences, not only in the Aegean, but also in Europe generally. ${ }^{58}$

In another important article on ancient DNA from 2017, a new study was published on the same topic, but specifically focused on the Aegean populations. ${ }^{59}$ A group of scientists (thirty-four) from leading research institutions across the globe examined the genetic origin of the Minoans and Mycenaeans. They collected genome-wide data from 19 individuals from Crete, from mainland Greece, and southwestern Anatolia. ${ }^{60}$ The distribution of

56. Stos-Gale, Gale, and Gilmore 30-31. The bronze objects excavated at Kastri comprise a tool hoard with two awls, nine chisels, a saw and two scraps of rolled sheet; in other parts of the site were found two small daggers, two flat axes and a spearhead. Several objects from the tool hoard have good parallels in Anatolian objects excavated at Troy and Thermi on Lesbos.

57. Ibid. 36.

58.This particular example was selected due to its location on the Cycladic island. There are no many Cycladic sites with so perfectly preserved Anatalian settlements.

59. Lazaridis, Mittnik, Paterson et al., 2017, 1.

60. Idem. 
the studied genetic material is listed in the footnote bellow (Figure 11.) ${ }^{61} \mathrm{In}$ addition, 332 ancient individuals from the literature, 2,614 modern humans, and 2 present-day Cretans were included. $^{62}$ (Figure 12).

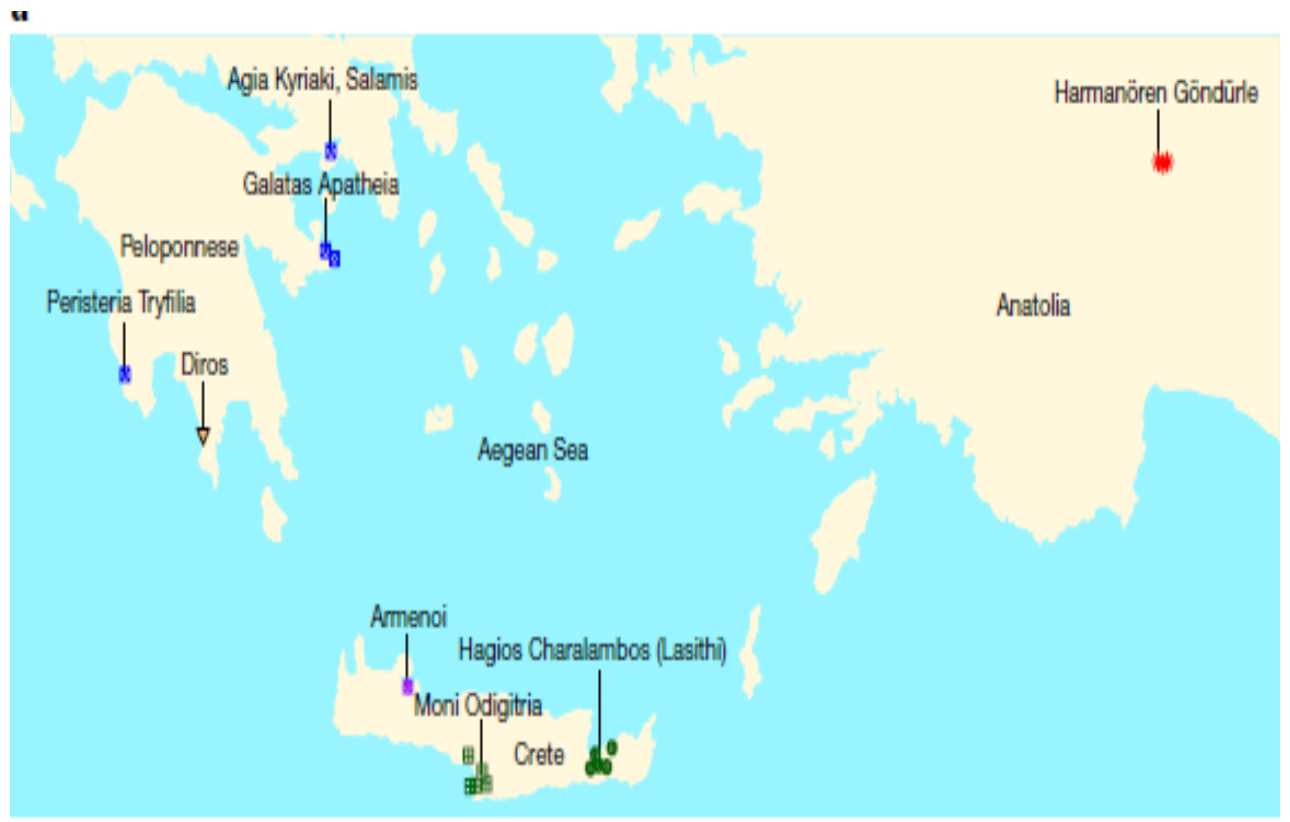

Figure 11. Geographic Locations of Newly Reported Ancient Data

Source: Lazaridis, Mittnik, and Patterson et al., 2017, 2.

61. Ibid. 2. 10 Minoans, 2900-1700 BCE (from Moni Odigitria, southern coast of central Crete, and from the cave of Hagios Charalambos, eastern Crete);

10. Minoans, 2900-1700 BCE (from Moni Odigitria, southern coast of central Crete, and from the cave of Hagios Charalambos, eastern Crete);

4 Mycenaeans, 1700-1200 BCE (from the western coast of the Peloponnese, from Argolis, and the island of Salamis);

1 post-Minoan from Armenoi, 1370-1340 BCE (western Crete);

1 Neolithic, 5400 BCE (from Alepotra Cave, southern Peloponnese);

3 Bronze Age Anatolians, 2800-1800 BCE (Harmanoren Gondurle, southwestern Anatolia, Turkey).

4 Mycenaeans, 1700-1200 BCE (from the western coast of the Peloponnese, from Argolis, and the island of Salamis);

1 post-Minoan from Armenoi, 1370-1340 BCE (western Crete);

1 Neolithic, 5400 BCE (from Alepotra Cave, southern Peloponnese);

3 Bronze Age Anatolians, 2800-1800 BCE (Harmanoren Gondurle, southwestern Anatolia, Turkey).

62. Idem. Detailed analysis is part of the publication. 


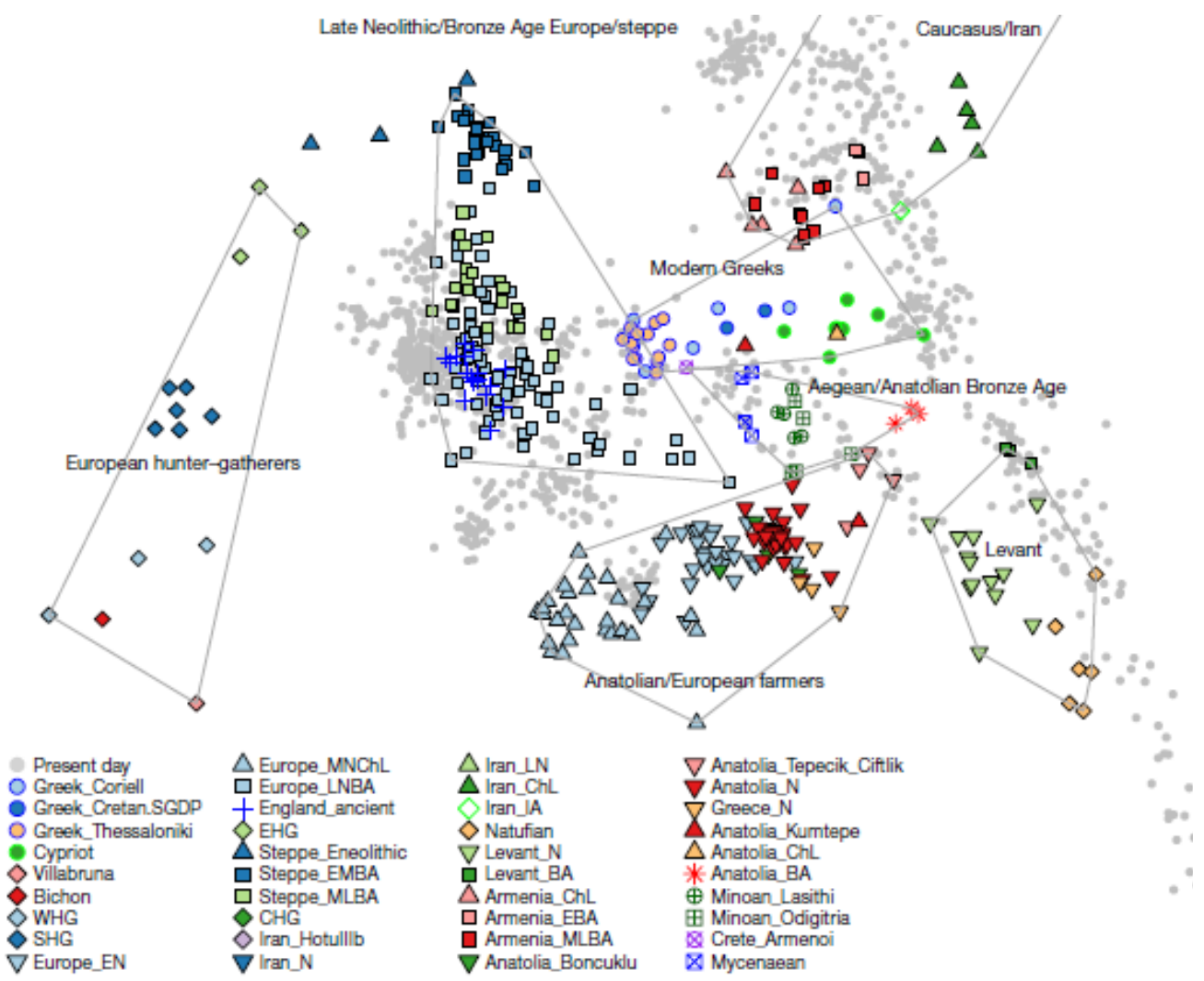

Figure 12. 334 Ancient Individuals with a Sample of 1,029 Present-day West Eurasians Including 30 Modern Greek Samples from Greece and Cyprus Source: Lazaridis, Mittnik, Patterson et al., 2017, 2.

The authors wanted to address several issues in their analysis, including genetic relations between Minoan and Mycenaean inhabitants and to respond to the important question of their relationship with the Anatolian populations. ${ }^{63}$ The study again revealed a strong connection with Anatolia and that all Bronze Age populations from the Aegean and Anatolia derived from the Anatolian Neolithic-related populations (62-86\%). In addition, another element of ancestry originated from the Eurasian steppe $(9-32 \%) .{ }^{64}$ Furthermore, the analysis revealed that the Minoans and Mycenaeans were homogeneous with the genetic coherency of southwestern Anatolians, sharing in both the local Anatolian Neolithic-like farmer ancestry and eastern Caucasus/Iran-related admixture. ${ }^{65}$ Armenia became one of the candidates to find a more proximate geographic location of the distinctive elements of eastern European/north Eurasian-related ancestry in Mycenaeans. Due to its location, Armenia could have admixed with Anatolian Neolithic-related farmers on either side of the Aegean proper $^{66}$ (Figure 13).

63. Lazaridis, Mittnik, Patterson et al., 2017, 1.

64. Ibid. 3.

65. Ibid. 5 .

66. Ibid. 4. 


\begin{tabular}{|c|c|c|c|c|c|c|c|c|c|c|c|c|c|}
\hline & & \multicolumn{4}{|c|}{ Ancestral sources } & \multicolumn{4}{|c|}{ Mixture proportions } & \multicolumn{4}{|c|}{ Standard errors } \\
\hline & Test & A & B & $\mathrm{c}$ & D & A & B & $\mathrm{c}$ & D & A & B & $\mathrm{c}$ & D \\
\hline \multirow{10}{*}{ ष्้ } & Anatolia_BA & & CHG & Anatolia_N $\mathrm{N}$ & Levant_N & & 0.319 & 0.618 & 0.063 & & 0.029 & 0.078 & 0.063 \\
\hline & Minoan_Odigitria & & CHG & Anatolia_N & & & 0.144 & 0.856 & & & 0.031 & 0.031 & \\
\hline & Minoan_Odigitria & & Iran_N & Anatolia_N & & & 0.137 & 0.863 & & & 0.032 & 0.032 & \\
\hline & Minoan_Lasithi & MA1 & CHG & Anatolia_N & & 0.001 & 0.152 & 0.847 & & 0.015 & 0.021 & 0.020 & \\
\hline & Minoan_Lasithi & Mota & CHG & Anatolia_N & & 0.004 & 0.154 & 0.842 & & 0.024 & 0.026 & 0.020 & \\
\hline & Mycenaean & AfontovaGora3 & CHG & Anatolia_N & & 0.133 & 0.126 & 0.741 & & 0.027 & 0.026 & 0.024 & \\
\hline & Mycenaean & AfontovaGora3 & Iran_N & Anatolia_N & & 0.161 & 0.086 & 0.754 & & 0.026 & 0.025 & 0.024 & \\
\hline & Mycenaean & EHG & Iran_N & Anatolia_ $\mathrm{N}$ & & 0.065 & 0.136 & 0.799 & & 0.016 & 0.022 & 0.024 & \\
\hline & Mycenaean & EHG & CHG & Anatolia_N & & 0.044 & 0.176 & 0.780 & & 0.016 & 0.023 & 0.024 & \\
\hline & Mycenaean & MA1 & CHG & Anatolia_N & & 0.052 & 0.159 & 0.789 & & 0.019 & 0.026 & 0.024 & \\
\hline \multirow{10}{*}{ 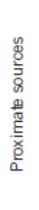 } & Anatolia_BA & & & Anatolia_ChL & Natufian & & & 0.908 & 0.092 & & & 0.039 & 0.039 \\
\hline & Anatolia_BA & & & Anatolia_ChL & Levant_BA & & & 0.892 & 0.108 & & & 0.114 & 0.114 \\
\hline & Anatolia_BA & & & Anatolia_ChL & Levant_N & & & 0.951 & 0.049 & & & 0.051 & 0.051 \\
\hline & Anatolia_BA & & & Anatolia_ChL & Anatolia_N $N$ & & & 0.935 & 0.065 & & & 0.062 & 0.062 \\
\hline & Mycenaean & & Armenia_MLBA & Anatolia_ $\mathrm{N}$ & & & 0.367 & 0.633 & & & 0.020 & 0.020 & \\
\hline & Mycenaean & & Armenia_ChL & Anatolia_N & & & 0.441 & 0.559 & & & 0.025 & 0.025 & \\
\hline & Anatolia_BA & & Anatolia_ChL & Minoan_Lasithi & & & 0.970 & 0.030 & & & 0.108 & 0.108 & \\
\hline & Mycenaean & Steppe_MLBA & & Minoan_Lasithi & & 0.175 & & 0.825 & & 0.017 & & 0.017 & \\
\hline & Mycenaean & Europe_LNBA & & Minoan_Lasithi & & 0.198 & & 0.802 & & 0.019 & & 0.019 & \\
\hline & Mycenaean & Steppe_EMBA & & Minoan_Lasithi & & 0.132 & & 0.868 & & 0.014 & & 0.014 & \\
\hline
\end{tabular}

Figure 13. Admixture Modeling of Bronze Age Populations

Source: Lazaridis, Mittnik, Patterson et al., 2017, 3.

Two other issues were addressed in Lazaridis, Mittnik, Patterson et al.: the physical appearance of Minoans and Mycenaeans and their connection with the present-day Greek population. ${ }^{67}$ One of the main obstacles was insufficient visual data for ancient European pigmentation. Therefore, the authors conducted phenotype prediction based on preserved Aegean frescos used as a source of physical attributes. In numerous examples, people are depicted with dark hair and dark eyes, and it is assumed that these were a realistic representation (Figures 14 and 15). It has been noted that "modern Greeks resemble the Mycenaeans but with some additional dilution of the early Neolithic ancestry." ${ }^{68}$

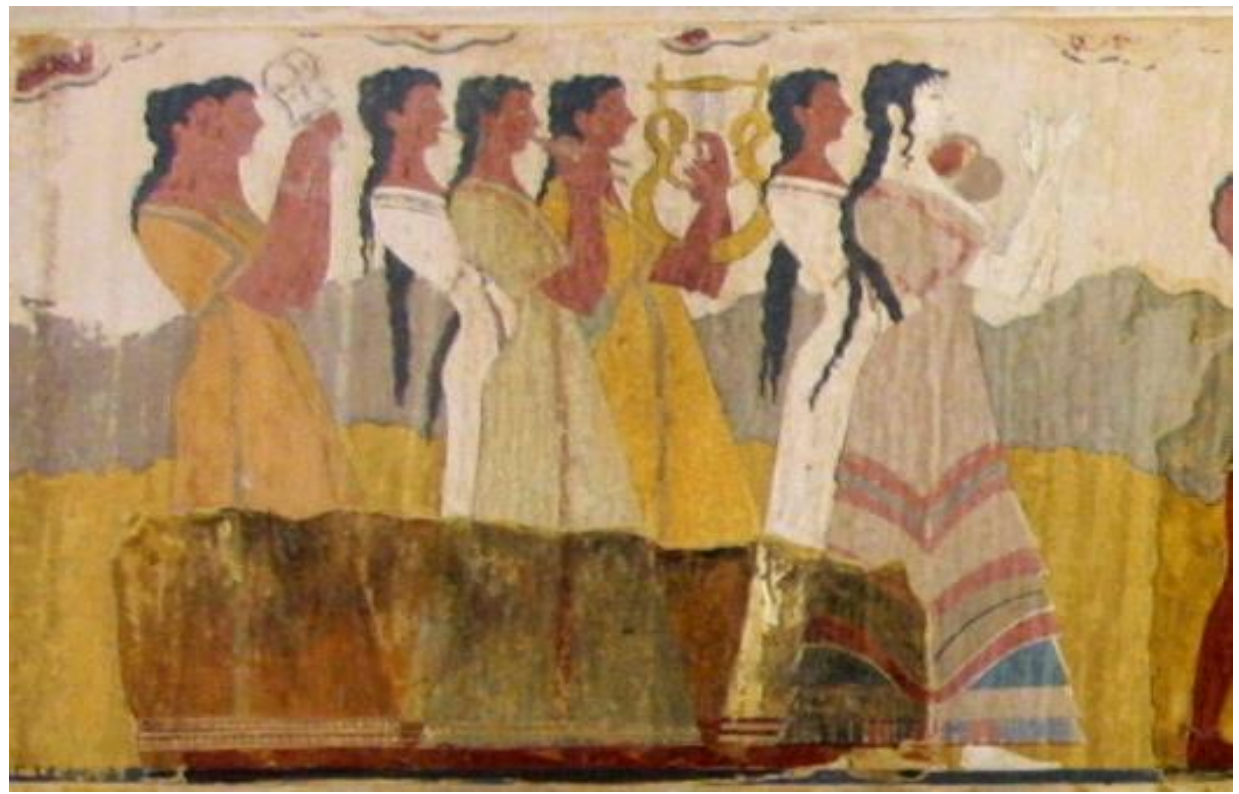

Figure 14. Segment of the Minoan Fresco of the Procession, Palace of Knossos, 1700-1400 BCE

Source: https://bit.ly/2GxF6Gm.

67. Idem.

68. Ibid.1. 


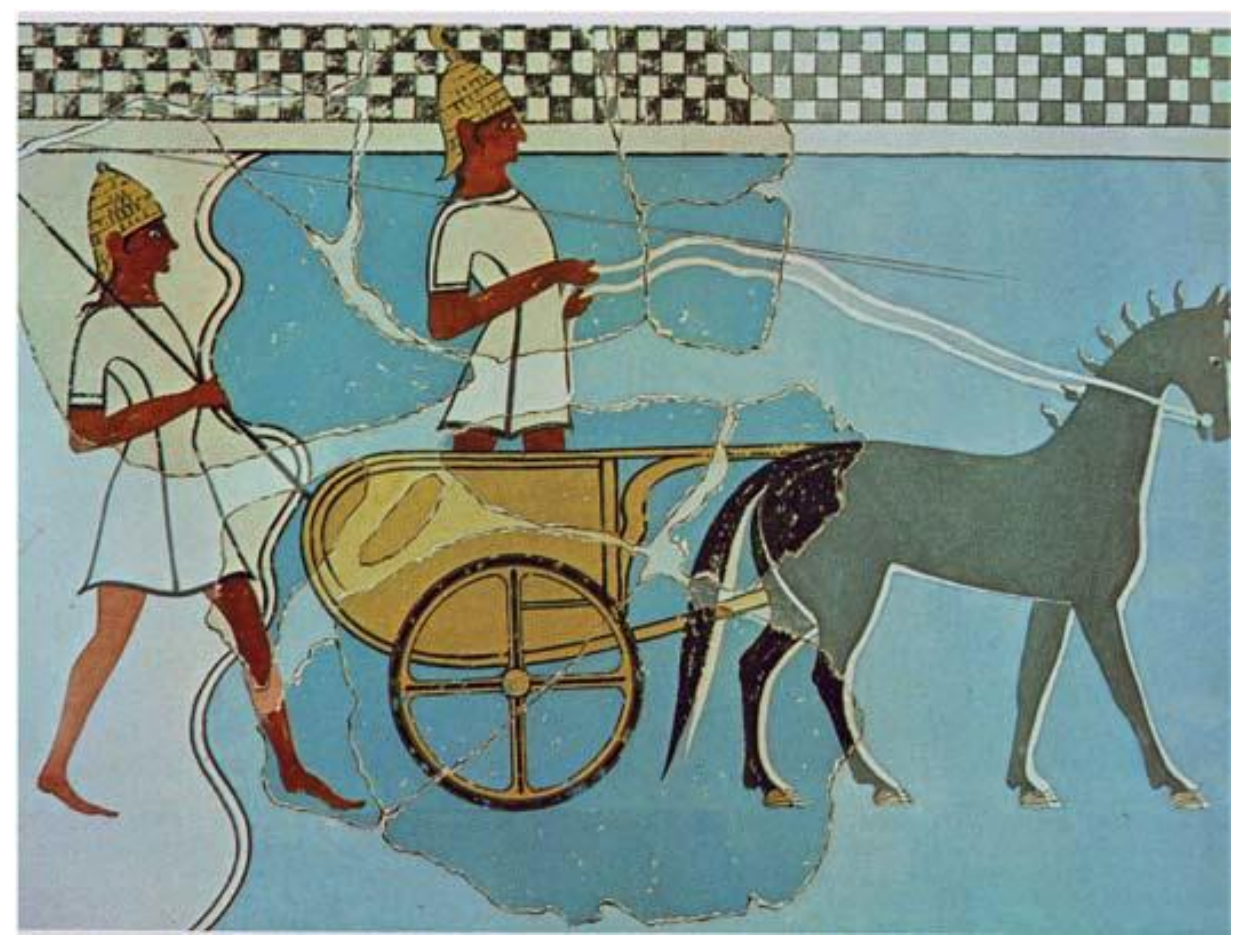

Figure 15. Mycenaean Fresco from the Palace At Pylos Depicting Two Warriors; One Rides His Chariot With Four-Spoked Wheels, $13^{\text {th }}$ century BCE Source: https://bit.ly/2V6uu4e.

The dark skin of the figures is a visual convention in Aegean art: males being represented with dark skin pigments and female figures with light skin pigmentation. When the figure was ethnically dark, it was depicted as such, as in the following fresco of foot solders where the Nubian warriors are depicted with darker skin than the remaining figure (Figure 16).

In this study of Minoan and Mycenaean genetic origins, the issue of the relations between present-day Greeks and their ancient ancestors was also briefly addressed and the conclusion is that modern Greeks are different from the Bronze Age populations, due to later additional admixture. ${ }^{69}$

One additional issue forms part of this study of the Aegean, and concerns the formation of the Greek language. The results were inconclusive. Traditionally, it is recognized that the deciphered Linear B script represents the earliest form of Greek. However, two other writing systems, already mentioned such as the Linear A script and the hieroglyphs (the Phaestos Disc, for example) remained uncoded. ${ }^{70}$ Therefore, taking all into consideration, in addition to lacking sufficient data on ancient Anatolian speakers, there remains strong doubt about Renfrew's "genetic-linguistic association. ${ }^{71}$

69. Lazaridis, Mittnik, Patterson et al., 2017, 4-5.

70. For more on writing see Helene Whittaker. "The Function and Meaning of Writing in the Prehistoric Aegean: Some reflections on the social and symbolic significance of writing from a material perspective," in Writing as Material Practice: Substance, Surface and Medium, ed. K. E. Piquette, and R. D. Whitehouse (London: Ubiquity Press, 2013), 108-109.

71. Ibid. 5. 


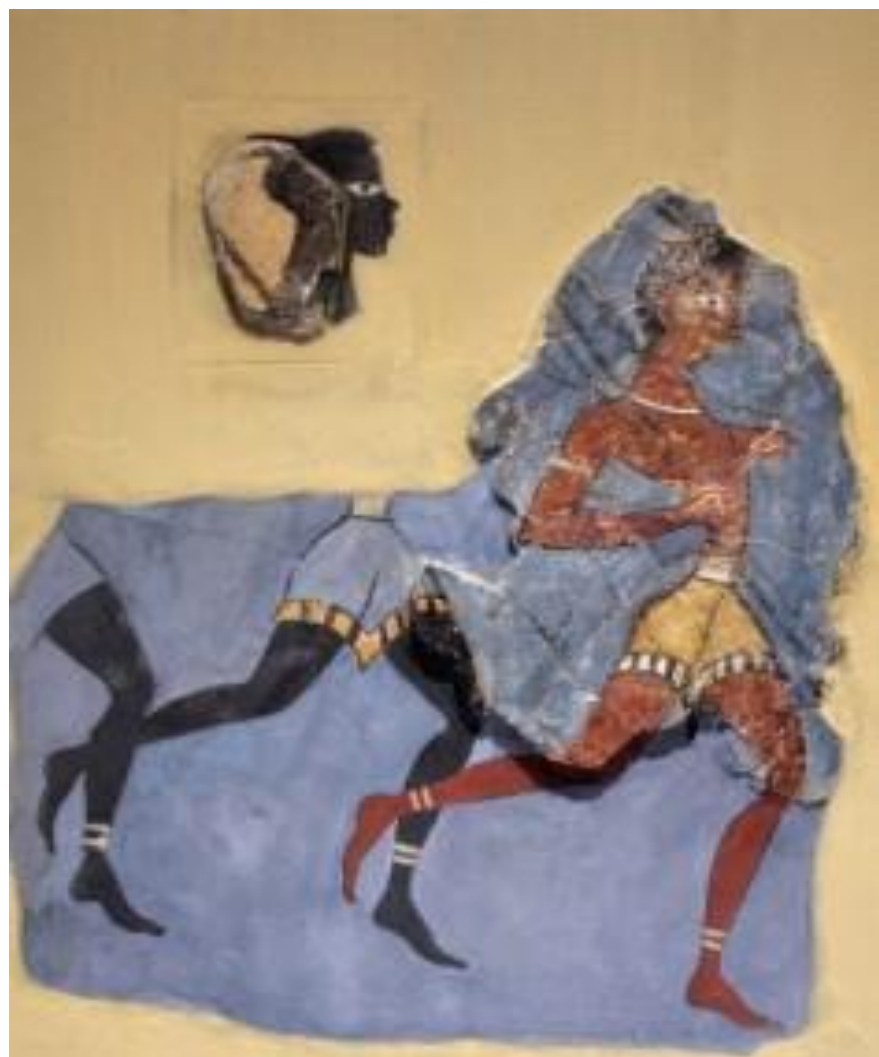

Figure 16. Minoan fresco known as the Captain of the Blacks from the "House of the Frescoes, " Palace at Knossos, 1400 BCE Source: https://bit.ly/2GyNHIL.

\section{Conclusion}

Recent technological advances in science, especially genome studies between 2013 and 2018 on ancient DNA, have made some revolutionary discoveries on the origin of Indo-European populations in Europe as well as on the issue of the spread of Indo-European languages. Scientists from leading research institutions across the globe have collected diverse ancient specimens, and in detailed investigative analysis, have arrived at some new results, as well as reversing some established theories. Archaeologist Colin Renfrew and anthropologist Marija Gimbutas formulated two hypotheses regarding the origin of Neolithic Europe and the Bronze Age populations.

Renfrew preferred the Anatolian connection of migratory movement to European land, previously established by Neolithic Indo-European farmers who continued with the agricultural advancement and the spread of diverse languages in a rather peaceful and gradual evolutionary process. Conversely, Gimbutas's hypothesis was based on the revolutionary influx of Kurgan invaders from the Russian steppes in several phases. Their technological superiority was based on wheeled vehicles, which enabled mobility, long travels, trade, and rapid economic prosperity. While Renfrew as an empirical scholar searched for archeological evidence to support his hypothesis, Gimbutas relied on her interdisciplinary, nontraditional method of 
archaeomythology to study artifacts as part of the overall cultural understanding of the past.

Both scholars benefited from the genome scientific studies of ancient DNA. In the case of the Anatolian connection, the source of influence remained correct, but the impact of migration as well as some language connection with agriculture was rejected. In addition, advancement in chemical analysis confirmed the strong possibility of Anatolian settlement in Kastri on the island of Syros during the Middle Bronze Age. Although most research has focused on the study of Aegean cultures, the Cyclades have been overlooked due to the lack of written records. The scientific study of metallurgy and tin alloys on Syros is then remarkable in our efforts to shed more light on the importance of different aspects of cultural production.

Genome analysis also confirmed Gimbutas's hypothesis of the Kurgan invaders and even Renfrew acknowledged this in his recent lecture in her honor. ${ }^{72} \mathrm{He}$ admitted that her nontraditional research methods had created doubts concerning her arguments for the origin of European Neolithic populations. Although her hypothesis was not completely supported by the genome study, it has revealed a record of large migratory movements coinciding with the Kurgan invasion. This type of study highlights the complexity of the research in general, and there is a definite need for more interdisciplinary, creative thinking and empirical, scientific methods implementing technology as a tool not just "technology for technology's sake."

Nonetheless, there are still some inconclusive results recorded due to insufficient existing research data. Additional studies are needed on a number of topics: ancient Anatolian burial sites and linguistics; focused discussions on Cycladic population and Aegean social system in general; and more crosscultural analysis to precisely determine admixture models commonly used in genome research. Even with current limitations, recent publications on the genetic origin of the Minoans and Mycenaeans with all their results are sufficiently revolutionary to look forward to more studies of this type in the near future.

\section{Bibliography}

Angel, J. Lawrence. "Early Neolithic Skeletons from Catal Huyuk: Demography and Pathology." In Anatolian Studies, 21 (1971), 77-98. https://bit.ly/2S7UPgA.

Anthony, David W., Bogucki, Peter, Comşa, Eugen, Marija Gimbutas, Jovanović, Borislav, Mallory J. P., and Milisaukas, Sarunas. "The 'Kurgan Culture,' IndoEuropean Origins, and the Domestication of the Horse: A Reconsideration." In Current Anthropology, 27 no. 4 (August-October 1986) 291-313. https://bit.ly/2X dlX1d.

Barber, R.L.N. and MacGillivray, J.A. "The Early Cycladic Period: Matters of Definition and Terminology." In American Journal of Archaeology, 84, no. 2 (April 1980), 141-157. https://bit.ly/2SJjLjK.

72. See the lecture at https://www.youtube.com/watch?v=pmv3J55bdZc. 
Broodbank, Cyprian. "Ulysses without Sails: Trade, Distance, Knowledge and Power in Early Cyclades." In World Archaeology, 23, no. 3 (February 1993), 315-31. https://bit.ly/2EhDcHu.

Broodbank, Cyprian. "The Longboat and Society in the Cyclades in the Keros-Syros Culture." In American Journal of Archaeology, 93, no. 3 (July 1989), 319-337. https://bit.ly/2TR6sdr.

Coleman, John E. "The Chronology and Interconnections of the Cycladic Islands in the Neolithic Period and the Early Bronze Age." In American Journal of Archaeology, 78, no.4 (October 1974), 333-344. https://bit.ly/2BDIADZ.

Fleming, Andrew. "The Myth of the Mother Goddess." In World Archaeology, 1, no. 2 (October 1969), 247-261. https://bit.ly/2TXI0qW.

Getz-Preziosi, Pat. Early Cycladic Sculpture, an Introduction. Malibu, Ca: The J. Paul Getty Museum, 1994.

Gimbutas, Marija. "The Indo-Europeans: Archaeological Problems." In American Anthropologist, 65, no 4 (August, 1963), 815-836. https://bit.ly/2NeIYfL.

Gimbutas, Marija. "An Ancient Art of Hunters and Fishers." In Archaeology, 8, no. 4 (December 1955), 268-277. https://bit.ly/2DYcTVc.

Haak, Wolfgang, Lazardis, Iosif, Patterson, Nick, et al. "Massive migration from the steppe was a source for Indo-European languages in Europe." In Nature 522 (June 2015), 207-211. doi=10.1308/nature14317.

Keller, Mara Lynn. "Theory of Early European Origins and the Contemporary Transformation of Western Civilization." In Journal of Feminist Studies in Religion, 12, no. 2 (Fall 1996), 73-90. https://bit.ly/2BHIZ7o.

Lazaridis, Iosif, Mallick, Swapan, Mittnik, Alissa et al. "Genetic origins of the Minoans and Mycenaeans." In Nature 548 (August 2017), 1-17. doi=10.1038/ nature23310.

Mallory, J.P. Barber. In Search of Indo-Europeans. London: Thames and Hudson, Ltd, 1989.

Mellaart, James. "The End of the Early Bronze Age in Anatolia and the Aegean." In American Journal of Archaeology, 62, no. 1 (January 1958), 9-33. https://bit.ly/ 2EhQyn6.

Renfrew, Colin. The Emergence of Civilization: The Cyclades and the Aegean in the Third Millennium BC. Oxford, UK: Oxford and Oakville, 1972/2011.

Renfrew, Colin. "The Origins of Indo-European Languages." In Scientific American, 261, no. 4 (October 1989), 106-115.

Shishlina, D.S., Kovalev, N., and Ibragimova, E. 2014. "Catacomb culture wagons of the Eurasian steppes." In Antiquity, 88 (June 2014), 378-394. https://bit.ly/2El7 rxk.

Sokal, Robert, Oden, Neal, and Thomson, Barbara. "Origins of the Indo-Europeans: Genetic Evidence." In Proceedings of the National Academy of Sciences of the United States of America, 89 no. 16 (August 15, 1992), 7669-7673. https://bit.ly/ 2V4acsj.

Stos-Gale, Z.A., Gale, N., and Gilmore G. "Early Bronze Age Trojan Metal Sources and Anatolians in the Cyclades." In Oxford Journal of Archaeology, 3, no 23 (May 2007), 1-22. doi=10.1111/j.1468-0092.1984.tb00120.x. 
Wheeler, Tamara Stech. "Early Bronze Age Burial Customs in Western Anatolia." In American Journal of Archaeology, 78, no. 4 (October 1974), 415-425. https://bit.ly/2TToxaI.

Whittaker, Helene. "The Function and Meaning of Writing in the Prehistoric Aegean: Some reflections on the social and symbolic significance of writing from a material perspective." In Writing as Material Practice: Substance, Surface and Medium, edited by K. E. Piquette, and R. D. Whitehouse, pp 105-121. London: Ubiquity Press, 2013.

Wichmann, Soren. Neolithic Linguistics. Max Planck Institute for Evolutionary Anthropology \& University of Copenhagen, (2004), 1-26. https://bit.ly/2TS45qU. 